\title{
Assessment of Hepatitis C virus (HCV) associated with hemodialysis patients in Thi-Qar province, Iraq
}

\author{
Ali Abdulhussein Khalaf ${ }^{1}$, Khwam R Hussein ${ }^{2}$ \\ \{alialhussein222@gmail.com ${ }^{1}$, krhussein@stu.edu.iq ${ }^{2}$ \} \\ Faculty of Graduate Studies, Southern Technical University, Iraq ${ }^{1}$ \\ Al-Nasiriyah Technical Institute, Southern Technical University, Iraq ${ }^{2}$
}

\begin{abstract}
Hepatitis is liver inflammation that can lead to many fatal health problems. Hepatitis $\mathrm{C}$ virus (HCV) is a blood-borne virus. Hemodialysis patients are at greater risk of acquiring HCV infection and this is a major global health problem. The study included 120 samples from patients who underwent dialysis at the age range of 20 to 87 years; males were $58.3 \%$ while $41.7 \%$ were females. The study confirmed that the percentage of $\mathrm{HCV}$ infection among Hemodialysis patients was 30\%, the high rate was in age groups 50-59 years $(33.3 \%)$, in males is high than females. There was an association between blood transfusion and $\mathrm{HCV}$ infection $(\mathrm{P}$ value $=0.037$ ). Also, the high percentage was in patients who remained more than 36 months $50.0 \%$ and twice sessions per week at $61.1 \%$. Six isolates were recorded in the global GenBank with accession numbers: MW947494MW947499. History of blood transfusions and a long period of Hemodialysis treatment were major risk factors for anti-HCV positive. HCV RNA testing should be conducted on all patients prior to Hemodialysis and blood before transfusion using PCR.
\end{abstract}

Keywords: HCV, Hemodialysis patients, PCR, NS5B and 5'UTR

\section{Introduction}

Hepatitis is a liver inflammation that can cause various health complications and death. Hepatitis $\mathrm{C}$ virus (HCV) is a virus that spreads through the bloodstream. This virus can cause both acute and chronic hepatitis. More than 170 million people are thought to be infected with the hepatitis $\mathrm{C}$ virus worldwide. An estimated 399000 people died of hepatitis C virus in 2016. However, 1,75 million new HCV infections have been reported worldwide in 2015 [1]. Hemodialysis (HD) is the most common method used for the treatment of advanced and permanent renal failure [2]. Hemodialysis patients are more likely to get HCV infection, which is a serious global health issue. Risk factors for HCV infection in patients with dialysis include the number of time a blood transfusions, HD period and dialysis mode, dialysis unit prevalence of HCV infection, prior organ transplantation, intravenous drug use, male sex, old age and HD unit nosocomial $\mathrm{HCV}$ transmission [3]. The prevalence of HCV infection among HD patients in various parts of the world ranges from $1 \%$ to $90 \%$ in a wide range. The prevalence rate is less than $5 \%$ in northern Europe, about $10 \%$ in southern Europe and the United States, and between 10\% and $70 \%$ in many northern African, Asian and South American countries [4]. However, it is high in 
developing countries: $18 \%$ in Brazil; $21 \%$ in Turkey; $24 \%$ in Tunisia; $45 \%$ in Saudi Arabia; and $78 \%$ in Morocco [5]. In Egypt between 52.3\% and 82.3\% [6]. In Iraq, in 2014, 42.6\% [7]. HCV is a small single-stranded RNA virus (approximately $55-65 \mathrm{~nm}$ ) in size, with a genome containing 9600 nucleotides HCV segments are both nonstructural (NS; P7, NS2, NS3, NS4A, NS4B, NS5A, and NS5B) and structural (core, E1, and E2)[8]. The viral RNA genome consists of 341 nucleotides in the 5 'untranslated region (5'UTR), a single long open reading frame (ORF) carrying 3010-3040 amino acids in a big viral polypeptide, and the 3' untranslated region (3'UTR) of varying length [9]. HCV can be categorized into at least seven major genotypes and various subtypes (a, b, c, etc.) based on genomic sequence variation [10].

$\mathrm{HCV}$ infection diagnosis is based on the diagnostic tests for two types of laboratory testing: serological tests for the identification of anti-HCV antibodies and molecular tests for detecting viral particulates. The HCV-RNA test polymerase chain reaction (PCR) confirm diagnosis and quantity of viral copies of the blood [11]. On the other hand, this study is aimed to evaluate the hepatitis $\mathrm{C}$ virus infection rates among dialysis patients in dialysis units in Thi-Qar province, south of Iraq as well as to assess the main risk factors that may contribute to the transmission of this virus among dialysis patients. In addition, study the non-structural 5B (NS5B) gene and the 5' untranslated region (5'UTR).

\section{Materials and Methods}

The current study (case control study) was carried out after the approval of the Ministry of Health, Thi-Qar Health Directorate. The samples were taken from Al-Hussein Center for kidney Dialysis at Al-Hussein Teaching Hospital in Thi-Qar province, south of Iraq for the period from $1^{\text {st }}$ of September 2020 to $31^{\text {st }}$ of March 2021. The samples were collected from 120 Iraqi patients who underwent dialysis at age range 20-87 years, 70 (58.3\%) were males and $50(41.7 \%)$ were females. A direct interview (questionnaire) was completed with each patient to record the following personal information (patient name, age, address, gender, Occupation, Marital Status). Also, associated risk factors that included (History of HCV diagnosis, the date of the first dialysis, the number of times dialysis, family history of $\mathrm{HCV}$, blood donation, the date of the blood donation, blood transfusion, the date of the blood transfusion, renal transfusion, the date of renal transfusion, previous surgery, the date of the previous surgery). In addition, chronic diseases as hypertension and diabetes were included. Blood samples $(5 \mathrm{ml})$ were drawn from each hemodialysis patients in this study (positive group and negative group of HCV) and collected in a sterile plastic tube. The blood samples were allowed to clot for 30 minutes at room temperature then centrifuged at $2000 \mathrm{gx}$ for 15 minutes for clear separation of serum. The serum was saved in sterile tube and analyzed by ELISA assay to detect anti HCV antibody using commercially available kits (RecombiLISA HCV Ab ELISA Kit, Biotech, USA). The serum was stored at $-20{ }^{\circ} \mathrm{C}$ until the future test by reverse transcription-PCR technique. HCV RNA was extracted from serum HD patients with anti-HCV positive using (QIAamp® Viral RNA Mini Kit, QIAGEN, Germany) according to manufacturer's instructions. RNA samples were converted to cDNA using (OneScript ${ }^{\circledR}$ Hot cDNA Synthesis Kit, abm, Canada). PCR was carried out to amplify the 5'UTR region (241bp in size) by the forward primer 5'ACTCCACCATAGATCATCCC-3' [12] and the reverse primer 5'AACACTACTCGGCTAGCAGT-3'. In addition, amplify the NS5B gene (826 bp in size) using the forward primer 5'-CAATWSMMACBACCATCATGGC-3' and the reverse primer 5'CAGG ARTTRACTGGAGTGTG-3' [13].

Amplification of cDNA was carried out in a final volume of $25 \mu \mathrm{l}$ reaction mixture using (GoTaq ${ }^{\circledR}$ Green Master Mix, Promega, USA) Which contains $5 \mu$ cDNA samples, GoTaq ${ }^{\circledR}$ 
Green Master Mix $12.5 \mu$, forward primer 1.5 $\mu$, reverse primer $1.5 \mu 1$ and Nuclease free water $4.5 \mu$ l. PCR amplification conditions were 1 cycle of pre- denaturation at $94^{\circ} \mathrm{C}$ for $5 \mathrm{~min}$ and 35 cycle of denaturation at $94^{\circ} \mathrm{C}$ for $30 \mathrm{sec}$, annealing at $56^{\circ} \mathrm{C}$ for $30 \mathrm{sec}$, extension at $72^{\circ} \mathrm{C}$ for 30 sec and 1 cycle of final extension at $72^{\circ} \mathrm{C}$ for $7 \mathrm{~min}$. Amplicon $(10 \mu \mathrm{l})$ was mixed with $(2 \mu \mathrm{l})$ bromophenol blue (loading buffer) and loaded in the wells of the $1.5 \%$ agarose gel. The cathode was connected to the well side of the unit and the anode to the other side. The gel was run at 80 $\mathrm{V}$ until the bromophenol blue tracking dye migrated to the end of the gel. The cDNA was observed by staining the gel with ethidium bromide and viewed with UV transilluminator. Also, the purified NS5B gene PCR products were directed to Bioneer Company in Korea for achieved the DNA sequencing by AB DNA sequencing system. Phylogenetic study was done based on national center for biotechnology information -basic local alignment search tool (NCBI-Blast) alignment documentation. The phylogenetic tree was created by using the Neighbor-Joining method and evolutionary analyses was performed in molecular evolutionary genetics analysis (MEGA X) program. The data was analyzed using the statistical software that was available statistical packages for social science-version 26 (SPSS). The Chi-Square (X2) test was used to evaluate these significant differences at level $\mathrm{p}<0.05$.

\section{Results}

The study included 120 cases of hemodialysis patients, using ELISA technique. The results were positive for $\mathrm{HCV}$ infection in $36(30 \%)$ of those while $84(70 \%)$ were negative for $\mathrm{HCV}$ infections (Figure 1)

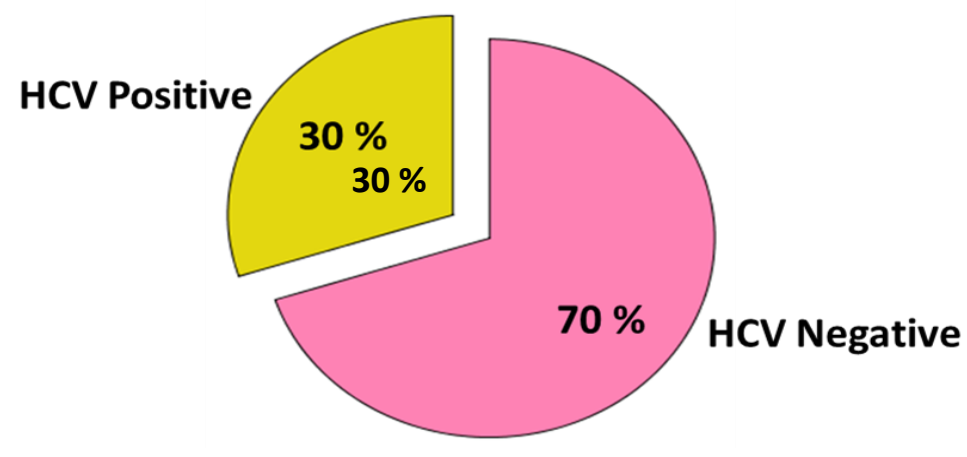

Fig. 1. Prevalence of hepatitis $C$ virus infection among hemodialysis patients

The results showed that the high rate of infections with HCV among hemodialysis patients was in the age groups $50-59$ years $(33.3 \%$ ) and, 60-69 years $22.2 \%$ then $40-49$ years was $19.4 \%$. Also, the results confirmed that males were high than females, where the percentage of males was $58.3 \%(n=70)$ while the incidence in females was $41.7 \%(n=50)$. where there were not significant differences $(\mathrm{P}=0.419)$ as shown in Table $(1,2)$.

In addition, the number of study patients who received a blood transfusion was $73(60.8 \%)$, where $27(22.5 \%)$ of them were anti-HCV positive. The statistical analysis showed significant differences $(\mathrm{P}=0.037)$. Also, the period of hemodialysis was high percentage $(50.0 \%)$ in patients who remained more than 36 months with significant differences $(P=0.001)$ Table (3). The high number of sessions per week for hemodialysis patients with HCV infection was twice per week 
$61.1 \%(n=22)$, followed by three times a week at a rate of $33.3 \%(n=12)$, where it appeared significant differences $(\mathrm{P}=0.003)$ (Table 4).

Table 1: Distribution of hemodialysis patients with anti-HCV positive according to gender

\begin{tabular}{cccccc}
\hline \multirow{2}{*}{ Variables } & groups & \multicolumn{2}{c}{$\begin{array}{c}\text { All } \\
\text { patients }\end{array}$} & \multicolumn{3}{c}{ HCV +ve } \\
\cline { 3 - 6 } & & NO. & $\%$ & NO. & $\%$ \\
\hline Gender & Male & 70 & 58.3 & 19 & 52.8 \\
& Female & 50 & 41.7 & 17 & 47.2 \\
& Chi-Square & $=0.653$ & $\mathrm{df}=1$ & P-value & $=0.41$ \\
\hline
\end{tabular}

Table 2: Distribution of hemodialysis patients with anti-HCV positive according to age group

\begin{tabular}{|c|c|c|c|c|c|}
\hline \multirow{2}{*}{ Variables } & \multirow{2}{*}{ groups } & \multicolumn{2}{|l|}{$\begin{array}{c}\text { All } \\
\text { patients }\end{array}$} & \multicolumn{2}{|c|}{$\mathrm{HCV}+\mathrm{ve}$} \\
\hline & & NO. & $\%$ & NO. & $\%$ \\
\hline & $20-29$ & 13 & 10.8 & 2 & 5.6 \\
\hline \multirow{8}{*}{$\begin{array}{l}\text { Age group } \\
\text { (years) }\end{array}$} & $30-39$ & 11 & 9.2 & 5 & 13.9 \\
\hline & $40-49$ & 14 & 11.7 & 7 & 19.4 \\
\hline & $50-59$ & 36 & 30.0 & 12 & 33.3 \\
\hline & $60-69$ & 31 & 25.8 & 8 & 22.2 \\
\hline & $70-79$ & 14 & 11.7 & 2 & 5.6 \\
\hline & $>80$ & 1 & 0.8 & 0 & 0 \\
\hline & $20-29$ & 13 & 10.8 & 2 & 5.6 \\
\hline & Chi-Square & $=7.765$ & $d f=6$ & P-value & 0.256 \\
\hline \multirow[t]{3}{*}{ Gender } & Male & 70 & 58.3 & 19 & 52.8 \\
\hline & Female & 50 & 41.7 & 17 & 47.2 \\
\hline & Chi-Square & $=0.653$ & $d f=1$ & P-value & $=0.41$ \\
\hline
\end{tabular}


Table 3. Risk factors among hemodialysis patients with HCV infection

\begin{tabular}{|c|c|c|c|c|c|}
\hline \multirow{2}{*}{ Risk factors } & \multirow{2}{*}{ groups } & \multirow{2}{*}{$\begin{array}{c}\begin{array}{c}\text { All } \\
\text { patients }\end{array} \\
\text { NO. }\end{array}$} & \multicolumn{3}{|c|}{$\mathrm{HCV}+\mathrm{ve}$} \\
\hline & & & $\%$ & NO. & $\%$ \\
\hline \multirow{6}{*}{$\begin{array}{l}\text { Length of time } \\
\text { on hemodialysis }\end{array}$} & $>12$ months & 35 & 29.2 & 7 & 19.4 \\
\hline & $12-24$ months & 39 & 32.5 & 7 & 19.4 \\
\hline & $25-36$ months & 14 & 11.7 & 4 & 11.1 \\
\hline & $<36$ months & 32 & 26.7 & 18 & 50.0 \\
\hline & Total & 120 & 100.0 & 36 & 100.0 \\
\hline & Chi-Square & $=17.356$ & $\mathrm{df}=3$ & $\mathrm{P}$-value & 0.001 \\
\hline \multirow{3}{*}{$\begin{array}{l}\text { History } \\
\text { of blood } \\
\text { transfusion }\end{array}$} & Yes & 73 & 60.8 & 27 & 22.5 \\
\hline & NO & 47 & 39.2 & 9 & 7.5 \\
\hline & Chi-Square & $=4.332$ & $\mathrm{df}=1$ & $\mathrm{P}$-value & 0.037 \\
\hline
\end{tabular}

Table 4. Relationship between the number of hemodialysis sessions per week and HCV infections

\begin{tabular}{ccccc}
\hline \multirow{2}{*}{$\begin{array}{l}\text { NO. of hemodialysis sessions } \\
\text { per week }\end{array}$} & $\begin{array}{c}\text { All } \\
\text { patients }\end{array}$ & & HCV +ve & \\
\cline { 2 - 5 } & NO. & $\%$ & NO. & $\%$ \\
\hline Once & 9 & 7.5 & 2 & 5.6 \\
Twice & 92 & 76.7 & 22 & 61.1 \\
Three times & 18 & 15.0 & 12 & 33.3 \\
Four times & 1 & 0.8 & 0 & 0 \\
Total & 120 & 100.0 & 36 & 100.0 \\
\hline
\end{tabular}

The results of PCR were performed after the amplification process. The positive results were distinguished when the cDNA band base pairs of sample equal to the target product size [14], then the products were visualized by UV trans-illuminator and using digital camera for photographing as in Figures (2 and 3). 


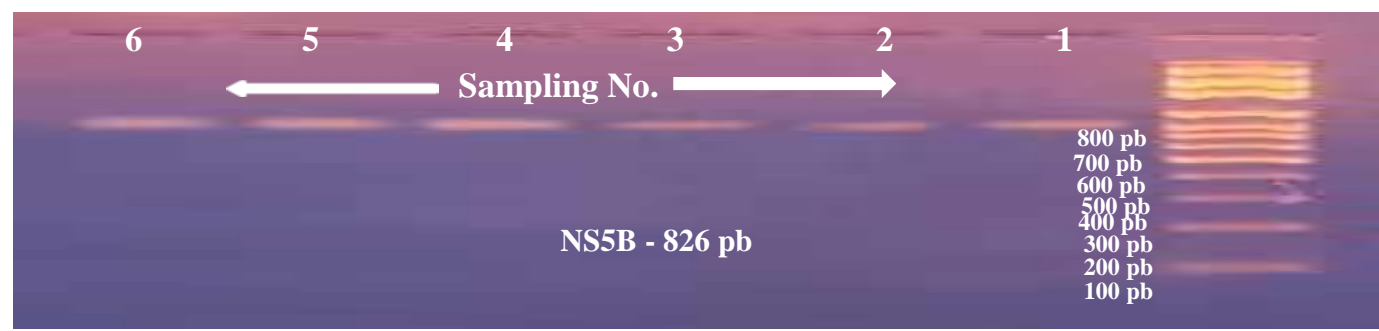

Fig. 2: Gel electrophoresis for PCR product from patients with hepatitis C, M: 100 bp DNA ladder, samples 1- 6: represent samples positive for NS5B.

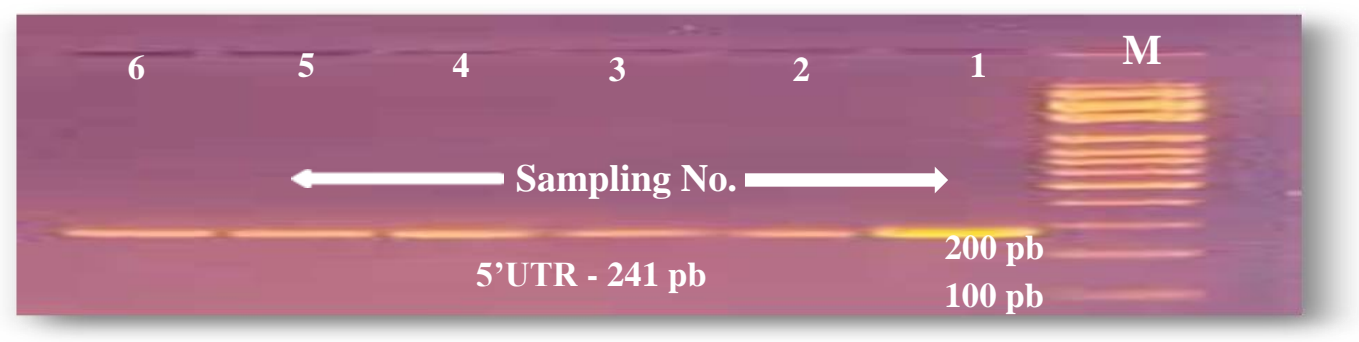

Fig. 3. Gel electrophoresis for PCR product from patients with hepatitis C M: 100 bp DNA ladder, samples 1- 6: represent samples positive for 5UTR.

In addition, after carried out viral RNA extraction for several samples and cDNA conversion then amplification have been completed, the study succeeded in getting 6 accession numbers then recorded them in the global GenBank as shown in Table (5). Also, The results of the current study, and through the Phylogenetic trees, showed isolates similar sequences to previously recorded isolates from neighboring countries such as Saudi Arabia and Iran, as well as isolates from countries of the world as the United Kingdom (UK), Thailand and the Netherlands Figure (4).

Table 5. Results sequence analysis for non-structural 5B (NS5B) Gene

\begin{tabular}{ccc}
\hline Sequences & Accession number & Genotypes \\
\hline Sq1 & MW947494 & $1 \mathrm{a}$ \\
Sq2 & MW947495 & $5 \mathrm{~b}$ \\
Sq3 & MW947496 & $1 \mathrm{a}$ \\
Sq4 & MW947499 & $3 \mathrm{a}$ \\
Sq5 & MW947497 & $5 \mathrm{~b}$ \\
Sq6 & MW947498 & $1 \mathrm{a}$ \\
\hline
\end{tabular}




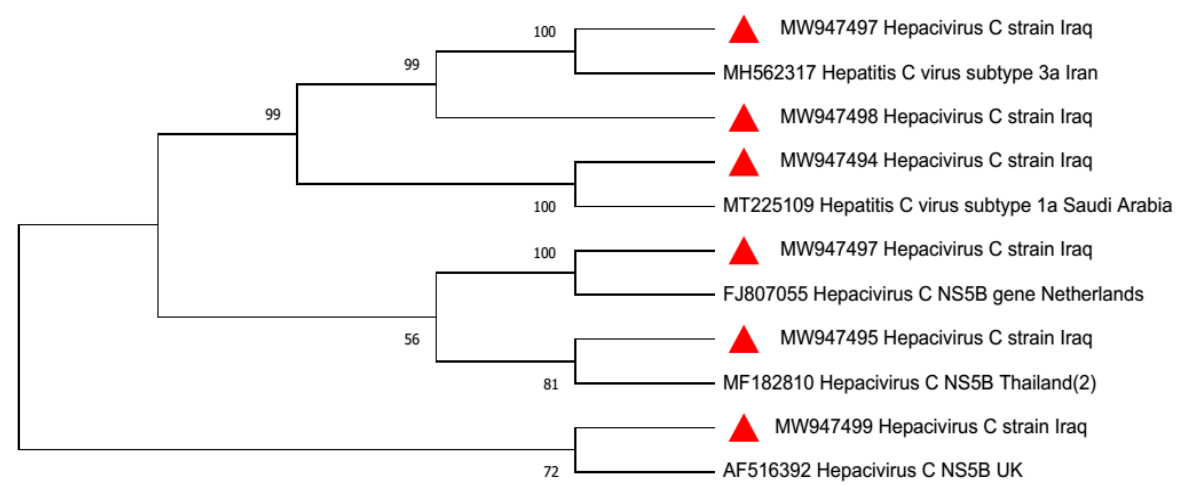

Fig. 4. Phylogenetic tree of studied isolates of HCV NS5B Gene with reference HCV strains in Genbank. Symbol ref $\boldsymbol{A}$ to local isolated have recorded.

\section{Discussions}

The prevalence of HCV in hemodialysis (HD) patients around the world ranges between 1 and $90 \%$, and the risk of $\mathrm{HCV}$ infection due to dialysis is estimated at $2 \%$ annually [4]. The results of study were that compared to previous studies from other regions of Iraq like in Basra was 42.6\% [7], in Baghdad 40.3\% [15], but they were high than from other part of Iraq such as in Sulaimani was $26.7 \%$ [16], Al-Anbar was $11.7 \%$ [17].In Iran were $8.1 \%$ and in Palestine were $24.7 \%$ [18], [19] but they were lower rate than Jordan 34.6\% [20] and in Egypt 39.7\% [21]. Also, other part of the world in the USA, and Southern Europe around 10\% while below 5\% in more countries of Northern Europe [22]. This variance due to differences in the risk factors that could impact HCV infection rates, or it because differences in the degree to which universal measures to avoid nosocomial transmission are implemented [23]. The results showed that the highest rate of infections was between the ages of 40-69 years, this occur because the older people have a high rate of renal failure diseases and need HD. This finding is agreement with previous studies [24]. Also, the study confirmed that males were high incidence than females this due to the males are more likely to be at risk and having anti-HCV positive than females [25]. The results are agreement with a previous studies have reported in Iraq [26], and in Iran [27]. But they were disagreement with the other study in Egypt [28]. Also, there were not significant differences ( $p>0.05$ ) between sex and anti-HCV positive in the study, this similar to another previously reported study [29]. HCV infections in HD patients have been significantly decreased when the number of blood transfusions has been reduced [30]. Several studies reported a significant relationship among history of blood transfusion and anti-HCV positive in HD patients [31]. The results were in agreement with the result of the current study that confirmed there was an association between blood transfusion and HCV infection, as the statistical analysis showed significant differences $(p<0.05)$. The statistical analysis showed that $\mathrm{HCV}$ infection depending on the length of a period on hemodialysis, where significant differences $(p<0.05)$ in the current study. The high percentage was in patients who remained more than 36 months. This result was similar to the findings of many studies conducted in different countries[32], who reported that the risk of contracting HCV infection increases significantly with the length of dialysis, this due to increase virus exposure, the long of period patients are in contact with hemodialysis equipment, or due to a lack of adequate anti-HCV antibody screening [33]. In addition, hemodialysis patients have weakened immune systems, 
and any minor lapse in universal control of HCV infection could expose them to the virus [34]. The results of the number of sessions per week for hemodialysis patients with HCV infection were an agreement with previous study showed that HD patients who had a history of sharing hemodialysis devices frequently weekly were at an increased risk of HCV infection, which due to all these HD patients had more potential to be exposed to HCV-contaminated medical equipment, HCV-contaminated objects, or the HCV-contaminated hands of medical staffs, possibly leading to nosocomial infections [35].

On the other hand, non-structural 5B (NS5B) Gene is a suitable gene region for studying the molecular epidemiology of HCV. HCV genotyping through nucleotide sequence analysis of NS5B is a reliable method for distinguishing between HCV subtypes [36]. Phylogenetic analysis of HCV genotypes and subtypes is a helpful molecular method for scientists to identify or estimate evolutionary relationships between individuals or organisms groups [37]. However, the 5 'untranslated region (5'UTR) is the most conserved region in the genome. It is often the best strategy for HCV genome detection [38]. For this reason, using the 5'UTR Gene for the purpose of HCV-RNA recommends for detection. The region controls genome replication and translation, and it can be used to diagnose this virus [39].

\section{Conclusions}

A history of blood transfusions as well as a longer period of HD treatment was the major risk factors for the development of anti-HCV positive. The 5'UTR Gene is often the best approach for detection of HCV-RNA and HCV genotyping across nucleotide sequence analysis of NS5B is a reliable manner for differentiating among HCV subtypes. In addition, HCV RNA easy should be performed on all patients prior to Hemodialysis patient and blood transfusion using PCR.

\section{References}

[1] Organization World Health, Global hepatitis report 2017. World Health Organization, 2017.

[2] B. H. Scribner, J. E. Z. Caner, R. Buri, and W. Quinton, "The technique of continuous hemodialysis," ASAIO J., vol. 6, no. 1, pp. 88-103, 1960.

[3] E. Nicolardi, A. Grieco, G. L. Rapaccini, and M. Pompili, "Natural history, diagnosis and treatment of chronic hepatitis B and C in hemodialysis patients," G. Ital. di Nefrol. Organo Uff. Della Soc. Ital. di Nefrol., vol. 27, no. 3, pp. 262-273, 2010.

[4] S. Marinaki, J. N. Boletis, S. Sakellariou, and I. K. Delladetsima, "Hepatitis C in hemodialysis patients," vol. 7, no. 3, pp. 548-558, 2015, doi: 10.4254/wjh.v7.i3.548.

[5] F. Fabrizi and P. Martin, "Health care-associated transmission of hepatitis B and C viruses in hemodialysis units," Clin. Liver Dis., vol. 14, no. 1, pp. 49-60, 2010.

[6] A. Afifi, "The Egyptian Renal Registry," 9th Annu. Rep. year, 2008.

[7] S. S. Shihab, H. A. Al-Hmudi, H. S. Al-Edani, and K. H. Mahdi, "Viral hepatitis infections in Basrah haemodialysis unit: serological diagnosis and viral loading," Eur. J. Exp. Biol., vol. 4, no. 2, pp. 106-112, 2014.

[8] C. Alpers et al., "KDIGO clinical practice guidelines for the prevention, diagnosis, evaluation, and treatment of hepatitis $\mathrm{C}$ in chronic kidney disease: introduction," Kidney Int., vol. 73, no. suppl. 109, pp. S6-S99, 2008.

[9] T. S. Gritsun and E. A. Gould, "The 3' untranslated regions of Kamiti River virus and Cell fusing agent virus originated by self-duplication," J. Gen. Virol., vol. 87, no. 9, pp. 2615-2619, 2006. 
[10] D. A Hassan, S. Q Maulud, R. H Saeed, and B. F Nore, "Seroprevalence and Genotypic Distribution Patterns of Hepatitis C Virus among Infected Patients from Erbil Province: Kurdistan/Iraq," Diyala J. Med., vol. 14, no. 1, pp. 84-93, 2018, doi: 10.26505/djm.14013640911.

[11] M. Jadoul et al., "Prevalence, incidence, and risk factors for hepatitis C virus infection in hemodialysis patients," Kidney Int., vol. 95, no. 4, pp. 939-947, 2019, doi: 10.1016/j.kint.2018.11.038.

[12] H. L. Zaaijer, H. T. M. Cuypers, H. W. Reesink, I. N. Winkel, P. N. Lelie, and G. Gerken, "Reliability of polymerase chain reaction for detection of hepatitis C virus," Lancet, vol. 341, no. 8847, pp. 722-724, 1993, doi: 10.1016/0140-6736(93)90488-3.

[13] S. Akkarathamrongsin et al., "Geographic distribution of hepatitis C virus genotype 6 subtypes in Thailand," J. Med. Virol., vol. 82, no. 2, pp. 257-262, 2010, doi: 10.1002/jmv.21680.

[14] V. Sgaramella, "YAC protocols. Methods in molecular biology, vol. 54," FEBS Lett., vol. 398, no. 2-3, pp. 338-338, 1998, doi: 10.1016/0014-5793(97)81273-2.

[15] A. S. Malik and H. M. H. AL-Rubaie, "Seroconversion rate of hepatitis C virus infection among haemodialysis patients in Al-Kadhimiya Teaching Hospital (dialysis unit)," Iraqi J. Med. Sci., vol. 9, no. 4, pp. 343-349, 2011.

[16] Z. S. Ramzi, A. A. Abdulla, A.-H. Tariq, and N. G. Al-Tawil, "Prevalence and risk factors for hepatitis C virus infection in hemodialysis pateints in Sulaimani," Zanco J. Med. Sci. (Zanco J Med Sci), vol. 14, no. 1 Special, pp. 44-50, 2010.

[17] J. I. Al-Mashhadani, "Hepatitis C virus infection among haemodialysis patients in $\mathrm{Al}$ Anbar governorate," IRAQI JOURNALOF COMMUNITY Med., vol. 20, no. 1, pp. 20 23, 2007.

[18] H. Al Zabadi, H. Rahal, and R. Fuqaha, "Hepatitis B and C prevalence among hemodialysis patients in the West Bank hospitals, Palestine," BMC Infect. Dis., vol. 16, no. 1 , pp. 1-5, 2015.

[19] R. Tajbakhsh, "Prevalence of hepatitis C and B virus infections among hemodialysis patients in Karaj, Iran," Saudi J. Kidney Dis. Transplant., vol. 26, no. 4, p. 792, 2015.

[20] M. A. Daw and A. A. Dau, "Hepatitis C virus in Arab world: a state of concern," Sci. World J., vol. 2012, 2012.

[21] H. A. Ahmed, Y. S. Yassine, A. R. Tawafe, and M. M. Ebazaway, "Epidemiological study of patients on regular haemodialysis at the Kafer El-Shakh Governorate, Egypt," Menoufia Med. J., vol. 28, no. 2, p. 267, 2015.

[22] C. Gómez-Gutiérrez, N. C. Chávez-Tapia, G. Ponciano-Rodríguez, M. Uribe, and N. Méndez-Sánchez, "Prevalence of hepatitis C virus infection among patients undergoing haemodialysis in Latin America," Ann. Hepatol., vol. 14, no. 6, pp. 807-814, 2015, doi: 10.5604/16652681.1171751.

[23] M. Al-Jamal, A. Al-Qudah, K. F. Al-Shishi, A. Al-Sarayreh, and L. Al-Quraan, "Hepatitis C virus (HCV) infection in hemodialysis patients in the south of Jordan," Saudi J. Kidney Dis. Transplant., vol. 20, no. 3, p. 488, 2009.

[24] S. Ashkani-Esfahani, S. M. Alavian, M. Salehi-Marzijarani, and et al Mahmood, "Prevalence of hepatitis $\mathrm{C}$ virus infection among hemodialysis patients in the MiddleEast: A systematic review and meta-analysis," World J. Gastroenterol., vol. 23, no. 1, p. 151, 2017.

[25] I. I. Sarhan and C. R. Kamel, "Prevalence of hepatitis C virus seroconversion among hemodialysis patients in Egypt," Egypt. Liver J., vol. 5, no. 2, pp. 34-39, 2015, doi: 10.1097/01.ELX.0000463167.48017.41. 
[26] Hasanain MH AL-Rubaie1 et al, "Seroconversion Rate of Hepatitis C Virus Infection among Haemodialysis Patients in AL-Kadhimiya Teaching Hospital (Dialysis Unit)," Iraqi JMS Publ. by Al-Nahrain Coll. Med., no. 1681-6579, pp. 343-349, 2011.

[27] M. J. Zahedi, S. D. Moghaddam, S. M. Alavian, and M. Dalili, "Seroprevalence of hepatitis viruses B, C, D and HIV infection among hemodialysis patients in Kerman Province, South-East Iran," Hepat. Mon., vol. 12, no. 5, p. 339, 2012.

[28] S. A. Senosy and E. M. El Shabrawy, "Hepatitis C virus in patients on regular hemodialysis in Beni-Suef Governorate, Egypt," J. Egypt. Public Health Assoc., vol. 91, no. 2, pp. 86-89, 2016, doi: 10.1097/01.EPX.0000484091.57255.c0.

[29] R. B. Fissell et al., "Patterns of hepatitis C prevalence and seroconversion in hemodialysis units from three continents: the DOPPS," Kidney Int., vol. 65, no. 6, pp. 2335-2342, 2004.

[30] M. P. Halle et al., "Hepatitis B, hepatitis C, and human immune deficiency virus seroconversion positivity rates and their potential risk factors among patients on maintenance hemodialysis in Cameroon," Iran. J. Kidney Dis., vol. 10, no. 5, p. 304, 2016.

[31] M. Espinosa et al., "Marked reduction in the prevalence of hepatitis $\mathrm{C}$ virus infection in hemodialysis patients: causes and consequences," Am. J. kidney Dis., vol. 43, no. 4, pp. 685-689, 2004.

[32] F. Joukar, S. Besharati, H. Mirpour, and F. Mansour-Ghanaei, "Hepatitis C and hepatitis B seroprevalence and associated risk factors in hemodialysis patients in Guilan province, north of Iran: HCV and HBV seroprevalence in hemodialysis patients," Hepat. Mon., vol. 11, no. 3, p. 178, 2011.

[33] W. A. Alashek, C. W. McIntyre, and M. W. Taal, "Hepatitis B and C infection in haemodialysis patients in Libya: prevalence, incidence and risk factors," BMC Infect. Dis., vol. 12, no. 1, pp. 1-8, 2012.

[34] A. Kashem et al., "Hepatitis C virus among hemodialysis patients in Najran: prevalence is more among multi-center visitors," Saudi J. Kidney Dis. Transplant., vol. 14, no. 2, p. 206, 2003.

[35] G. Cai et al., "Factors Correlating to the Development of Hepatitis C Virus Infection in Hemodialysis Patients-Findings Mainly from Asiatic Populations: A Systematic Review and Meta-Analysis," Int. J. Environ. Res. Public Health, vol. 16, no. 8, p. 1453, 2019.

[36] D. G. Murphy, B. Willems, M. Deschênes, N. Hilzenrat, R. Mousseau, and S. Sabbah, "Use of sequence analysis of the NS5B region for routine genotyping of hepatitis C virus with reference to $\mathrm{C} / \mathrm{E} 1$ and 5' untranslated region sequences," J. Clin. Microbiol., vol. 45, no. 4, pp. 1102-1112, 2007.

[37] D. Mutimer et al., "EASL Clinical Practice Guidelines: management of hepatitis C virus infection," J. Hepatol., vol. 60, no. 2, pp. 392-420, 2014.

[38] K. Hesamizadeh, S. M. Alavian, A. N. T. Shabankareh, and H. Sharafi, "Molecular tracing of hepatitis c virus genotype 1 isolates in iran: a NS5B phylogenetic analysis with systematic review," Hepat. Mon., vol. 16, no. 12, 2016.

[39] G. K. Alagoz et al., "Hepatitis C virus genotype distribution in Turkey remains unchanged after a decade: performance of phylogenetic analysis of the NS5B, E1, and 5'UTR regions in genotyping efficiency," Turk J Gastroenterol, vol. 25, no. 4, pp. 405410, 2014. 